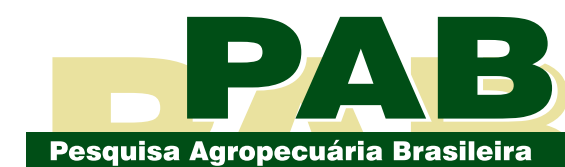

ISSN 1678-3921

Journal homepage: www.embrapa.br/pab

For manuscript submission and journal contents, access: www.scielo.br/pab

\title{
Cupuaçu tree genotype selection for an agroforestry system environment in the Amazon
}

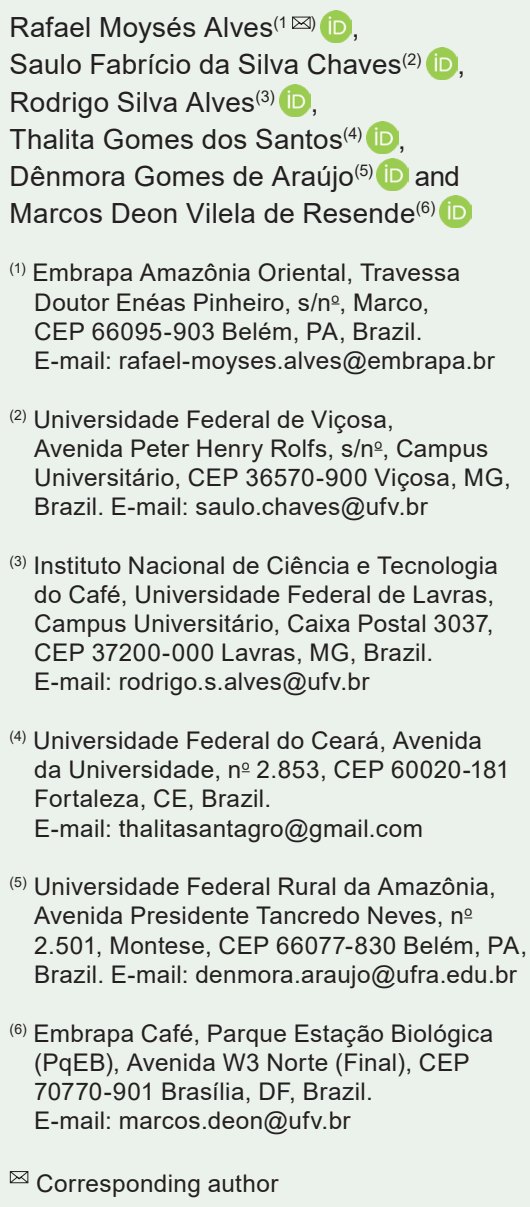

(5) Universidade Federal Rural da Amazônia, Avenida Presidente Tancredo Neves, $\mathrm{n}$ 2.501, Montese, CEP 66077-830 Belém, PA, Brazil. E-mail: denmora.araujo@ufra.edu.br

(6) Embrapa Café, Parque Estação Biológica (PqEB), Avenida W3 Norte (Final), CEP 70770-901 Brasília, DF, Brazil. E-mail:marcos.deon@ufv.br

$凶$ Corresponding author

Received

July 10, 2020

Accepted

December 02, 2020

How to cite

ALVES, R.M.; CHAVES, S.F. da S.; ALVES, R.S.; SANTOS, T.G. dos; ARAÚJO, D.G. de; RESENDE, M.D.V. de. Cupuaçu tree genotype selection for an agroforestry system environment in the Amazon. Pesquisa Agropecuária Brasileira, v.56, e02139, 2021. DOI: https://doi.org/10.1590/S1678-3921. pab2021.v56.02139.

\begin{abstract}
The objective of this work was to select cupuaçu (Theobroma grandiflorum) tree progenies and individuals based on their agronomic traits, and, indirectly, to identify those adapted to an agroforestry system (AFS) environment in the Brazilian Amazon. For this purpose, 25 full-sib progenies were planted and tested in consortium with black pepper (Piper nigrum), banana (Musa spp.), and bacuri (Platonia insignis) trees. The experiment was carried out in a randomized complete block design, with five replicates and three plants per plot, from 2005 to 2019. For the statistical analyses, the phenotypic averages for production and incidence of witches' broom disease, evaluated during 11 harvests, were used. Superior progenies and individuals were identified using the mixed model methodology (REML/BLUP), which led to the selection of ten plants from five families with superior agronomic traits. Cupuaçu tree progenies $6,36,37,49$, and 52 are the ones that best adapt to the environment of a multispecies AFS in the Amazon region because of their agronomic traits under competitive conditions. Ten matrices show agronomic potential and indirect adaptation to the AFS and can be used as clonal cupuaçu cultivars in this environment.
\end{abstract}

Index terms: Theobroma grandiflorum, fruit tree breeding, genetic selection, REML/BLUP.

\section{Seleção de genótipos de cupuaçu para um ambiente de sistema agroflorestal na Amazônia}

Resumo - O objetivo deste trabalho foi selecionar progênies e indivíduos de cupuaçuzeiro (Theobroma grandiflorum) com base em características agronômicas e, indiretamente, identificar aqueles adaptados a um ambiente de sistema agroflorestal (SAF) na Amazônia brasileira. Para tanto, 25 progênies de irmãos completos foram plantadas e testadas em consórcio com pimentado-reino (Piper nigrum), banana (Musa spp.) e bacuri (Platonia insignis). $\mathrm{O}$ experimento foi realizado em delineamento de blocos ao acaso, com cinco repetições e três plantas por parcela, de 2005 a 2019. Para as análises estatísticas, foram utilizadas as médias fenotípicas de produção e incidência da vassoura de bruxa avaliadas durante 11 safras. Progênies e indivíduos superiores foram identificados pela metodologia de modelos mistos (REML/ BLUP), o que resultou na seleção de dez plantas de cinco famílias com características agronômicas superiores. As progênies de cupuaçu 6, 36, 37, 49 e 52 são as que melhor se adaptam ao ambiente de um SAF multiespécies na região amazônica, em razão de suas características agronômicas em condições competitivas. Dez matrizes apresentam potencial agronômico e adaptação indireta ao SAF e podem ser utilizadas como cultivares clonais de cupuaçu nesse ambiente.

Termos para indexação: Theobroma grandiflorum, melhoramento de fruteiras, seleção genética, REML/BLUP. 


\section{Introduction}

The cupuaçu tree [Theobroma grandiflorum (Willd. ex. Spreng.) Schum.] is an arboreal species native to the Amazon, whose fruit are used to produce sweets, juice, ice creams, and jellies, among other products (Oliveira \& Genovese, 2013).

The Amazon has been identified as the only reserve of cupuaçu genetic variability, and it is also the center of the species' diversity. However, this region has undergone significant anthropogenic pressure through predatory exploitation and transformation of its natural landscape, with the consequent genetic erosion of this plant resource (Alves et al., 2007). Therefore, there is a need to understand the remaining genetic variability of the species. Since the late 1980s, Embrapa Amazônia Oriental has been conducting a genetic breeding program of the species in the state of Pará, Brazil, which aims to develop genotypes with superior levels of fruit production and resistance to the fungus Moniliophthora perniciosa (Stahel) Aime \& Phillips Mora, an etiological agent of witches' broom disease and the main pest that affects the cupuaçu tree cultivation (Alves et al., 2009).

The most cupuaçu cultivation is carried out in agroforestry systems (AFSs), mainly in the northeastern Pará (Barros et al., 2009). AFSs are productive systems in which land is managed in a consortium, using a range of tree species to promote economic and ecological gains (Silva, 2013). Within AFSs, different plant strata can be created in an attempt to replicate the native forest structure, in which trees and shrubs are considered basic elements, combining floristic diversity with the environmental characteristics of the region in which they are established (Paludo \& Costabeber, 2012).

In addition to providing producers with genetic materials that meet their needs, such as high levels of fruit productivity and resistance to phytopathogens, the selection of genotypes adapted to conditions of interspecific competition for light, water, and nutrients that normally occur in AFS environments (Giustina et al., 2017) should be incorporated into the objectives of species breeding programs. Currently, researches trying to develop genotypes for these conditions are very rare, especially those involving perennial species. Alves et al. (2020) report results obtained with Swietenia macrophylla King. and cupuaçu tree, when they identified genotypes with the mentioned traits.
The objective of this work was to select cupuaçu progenies and individuals for their superiority in fruit production and resistance to witches' broom disease, and, indirectly, to select better adapted individuals to the agroforestry system environment.

\section{Materials and Methods}

The experiment was carried out over 14 years, from 2005 to 2019 , on a rural property in the municipality of Tomé Açu $\left(02^{\circ} 32^{\prime} 53.1^{\prime \prime} \mathrm{S}, 48^{\circ} 15^{\prime} 52.8^{\prime \prime} \mathrm{W}\right.$, at $45 \mathrm{~m}$ altitude), in the state of Pará, Brazil. The soil is classified as Latossolo Amarelo distrófico argissólico according to Brazilian soil classification system (Santos et al., 2018), i.e., Oxisol, and it is deep and well drained, with a medium texture. The climate in the region is classified as Ami, according to the KöppenGeiger's classification, with $2,716 \mathrm{~mm}$ mean annual precipitation, $85 \%$ relative air humidity, and $26.4^{\circ} \mathrm{C}$ mean annual temperature (Bolfe \& Batistella, 2011).

The experimental genetic material consisted of 25 full-sib progenies from the cupuaçu genetic breeding program established by Embrapa Amazônia Oriental, in the municipality of Belém, in the state of Pará, Brazil. The parents used to develop the studied progenies include primary clones, which were previously introduced by Embrapa: 'BRS Coari' (174); 'BRS Codajás' (186); 'BRS Manacapuru' (215); and 'BRS Belém' (286), using the cupuaçu controlled-pollination technique, reported by Venturieri \& Ribeiro Filho (1995).

The AFS established for the present study consisted of an area of 0.9 ha, composed of four species: black pepper trees (Piper nigrum L.) planted in double rows of $2 \times 2 \mathrm{~m}$ and $4 \mathrm{~m}$ apart (1,440 plants); free standing cupuaçu seedlings planted at $6 \times 4 \mathrm{~m}$ spacing (375 plants), interspersed with banana tree seedlings (Musa spp.) in the planting row, originated from rhizomes, at the same spacing (375 plants); and grafted seedlings of bacuri (Platonia insignis Mart.) planted at 18x10 m spacing (49 plants) (Figura 1).

All species were planted in February 2005, after mechanized clearing of the area and individual planting hole preparation. The experiment was conducted using a randomized complete block design, with 25 cupuaçu progenies, five replicates, and three plants per plot, for a total of 375 plants. The thinning dynamic of the temporary crop (banana) began in the fourth year after planting, and by the end of the sixth 
year, all banana clusters had been removed. The same occurred with the black pepper trees which remained in the field until the seventh year, at which point they were removed because they were affected by fusarium disease. From that point on, only bacuri and cupuaçu remained in the AFS.

The collection of data related to cupuaçu production began two years after planting, during the 2007/2008 harvest, and continued until the 2018/2019 harvest, for a total of 11 harvests. Data collected at each harvest included the number of fruit produced per plant and the average weight of the fruit for each plant, using a sample of five fruit per plant. Thus, for each harvest, fruit production ( $\mathrm{kg}$ per plant) was estimated with
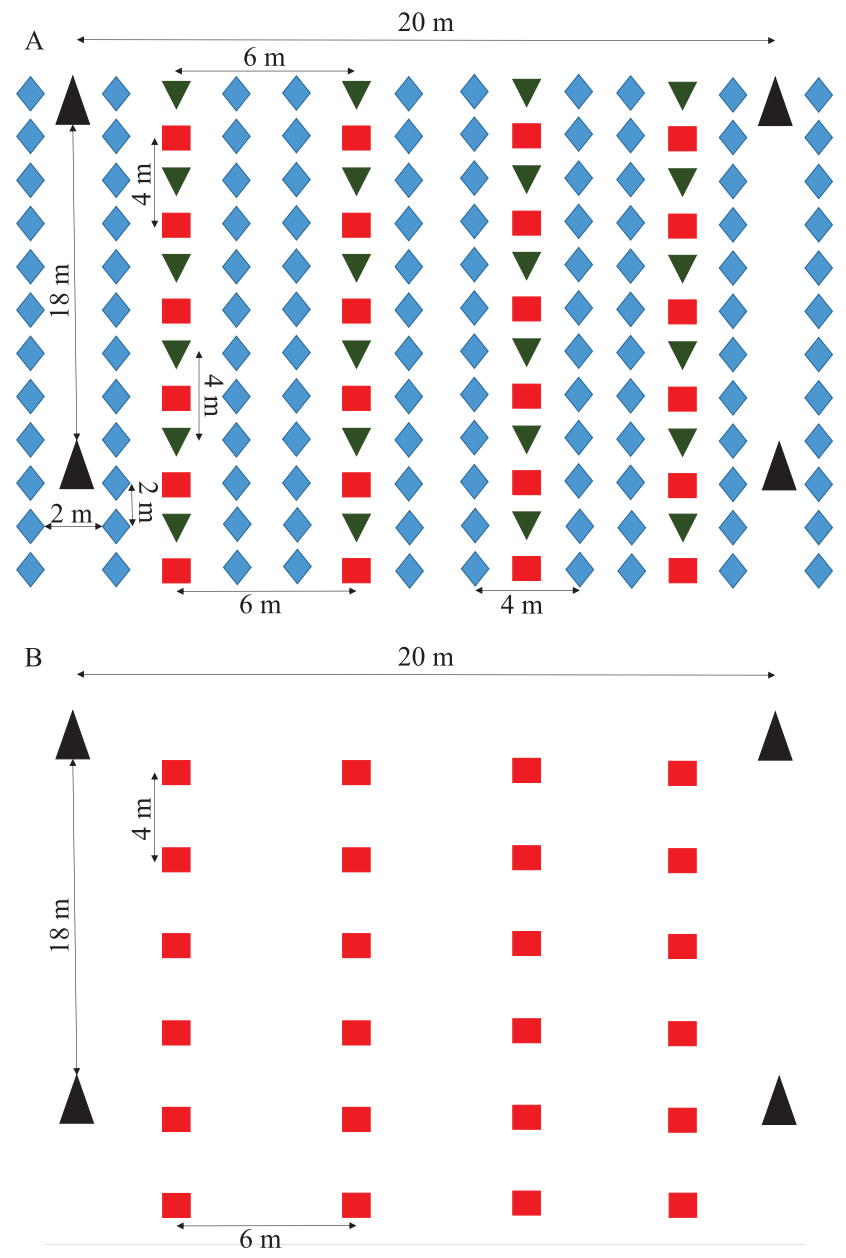

$\checkmark$ Piper nigrum $\triangle \begin{aligned} & \text { Platonia } \\ & \text { insignis }\end{aligned} \nabla$ Musa spp. $\square \begin{aligned} & \text { Theobroma } \\ & \text { grandiflorum }\end{aligned}$

Figure 1. Spatial distribution of species in the agroforestry system in the implantation (A) and in the maturation period (B). the formula: production $=$ number of fruit $\times$ mean fruit weight. The rate of witches' broom disease was also estimated based on the following ratio: number of plants with symptoms of the disease / number of healthy plants.

For statistical analyses, the phenotypic averages of production and incidence of witches' broom disease, evaluated during 11 harvests, were used. The statistical analyses were performed using the mixed model methodology (REML/BLUP) in the SELEGENREML/BLUP software (Resende, 2016), in which the components of variance were estimated by the REML method (Patterson \& Thompson, 1971), and the genetic values were predicted by the BLUP method (Henderson, 1975) simultaneously. The following statistical model was used:

$$
\mathrm{y}=\mathrm{Xr}+\mathrm{Zg}+\mathrm{Wp}+\mathrm{e},
$$

in which: $y$ is the vector of phenotypic data; $r$ is the vector of replicate effects (assumed to be fixed) added to the general average; $g$ is the vector of individual genotypic effects (assumed to be random) $\left[\mathrm{g} \sim \mathrm{N}\left(0, \sigma_{\mathrm{g}}^{2}\right)\right.$, in which $\sigma_{\mathrm{g}}^{2}$ is the genotypic variance among full-sib progenies]; $p$ is the vector of plot effects (assumed to be random) [ $\mathrm{p} \sim \mathrm{N}\left(0, \sigma_{\mathrm{p}}^{2}\right)$, in which $\sigma_{\mathrm{p}}^{2}$ is the environmental variance between plots]; and e is the vector of residuals (random) $\left[\mathrm{e} \sim \mathrm{N}\left(0, \sigma_{\mathrm{e}}^{2}\right)\right.$, which $\sigma_{\mathrm{e}}^{2}$ is the residual variance within a plot]. The capital letters represent the incidence matrices for these effects.

The significance of the random effects of the statistical model was tested by the likelihood ratio test (LRT) (Wilks, 1938) using the Chi-square statistics, with one degree of freedom, and 0.05 type I probability of error. The individual phenotypic variance $\left(\sigma_{\mathrm{f}}^{2}\right)$, the individual narrow-sense heritability $\left(h_{a}^{2}\right)$, the coefficient of determination of plot effects $\left(c_{p}^{2}\right)$, the average heritability of progenies $\left(\mathrm{h}_{\mathrm{mp}}^{2}\right)$, the accuracy of progenies selection $\left(\mathrm{r}_{\mathrm{gg}}\right)$, and the additive heritability within a plot $\left(\mathrm{h}_{\mathrm{ad}}^{2}\right)$ were estimated using the following expressions, respectively (Resende et al., 2014):

$$
\begin{aligned}
& \sigma_{\mathrm{f}}^{2}=\sigma_{\mathrm{g}}^{2}+\sigma_{\mathrm{p}}^{2}+\sigma_{\mathrm{e}}^{2} ; \mathrm{h}_{\mathrm{a}}^{2}=2 \sigma_{\mathrm{g}}^{2} / \sigma_{\mathrm{f}}^{2} ; \mathrm{c}_{\mathrm{p}}^{2}=\sigma_{\mathrm{p}}^{2} / \sigma_{\mathrm{f}}^{2}, \\
& \mathrm{~h}_{\mathrm{mp}}^{2}=\sigma_{\mathrm{g}}^{2} /\left[\sigma_{\mathrm{g}}^{2}+\left(\sigma_{\mathrm{p}}^{2} / \mathrm{r}\right)+\left(\sigma_{\mathrm{e}}^{2} / \mathrm{rn}\right)\right], \\
& \mathrm{r}_{\mathrm{gg}}=\sqrt{\mathrm{h}_{\mathrm{mp}}^{2}} \text { and } \mathrm{h}_{\mathrm{ad}}^{2}=\sigma_{\mathrm{g}}^{2} / \sigma_{\mathrm{r}}^{2},
\end{aligned}
$$

in which: $r$ is the number of replicates (5); and $\mathrm{n}$ is the number of plants per plot (3). 
The progenies with the highest predicted genetic values for the two fruit production traits that maintained ortets with a low incidence of witches' broom disease $(<20 \%)$ were prioritized in individual selection. Individuals were ranked based on the predicted genetic values, considering the selection of possible genitors, and the predicted genotypic values, considering the selection of clones for the trait fruit production per plant. This trait was chosen as it is the most economically relevant, since it incorporates both the traits number of fruit and average weight of fruit. Therefore, the selection of individuals was not only based on the previously selected progenies, but also considered the ranking for the genetic and genotypic values and incidence of $M$. perniciosa.

To avoid a significant reduction in the genetic variability of the breeding population, only two ortets per progeny were selected, to mitigate the risks of resistance breaking and the occurrence of incompatibility that is common in the species and can cause yield diminishing (Alves et al., 2017). The temporal distribution of the productive period of the selected individuals was also evaluated, for which plants with greater production concentrated in the last months of the year (beginning of the harvest) were classified as early, plants with greater production in the first four months of the year (middle of the harvest) were classified as regular, and plants with greater production in the period from May to July (end of the harvest) were classified as late.

\section{Results and discussion}

Cupuaçu fruit production began two years after planting, and the fourth harvest showed an increase of $666 \%$ in the number of fruit over the first harvest (Figure 2). At that point, the production in the area stabilized, with minimal fluctuations in the subsequent seven harvests. Both the rapid evolution in the initial production, and the variations in production in the final harvests can be attributed to the same conditioning factor. Initially, the area was equipped

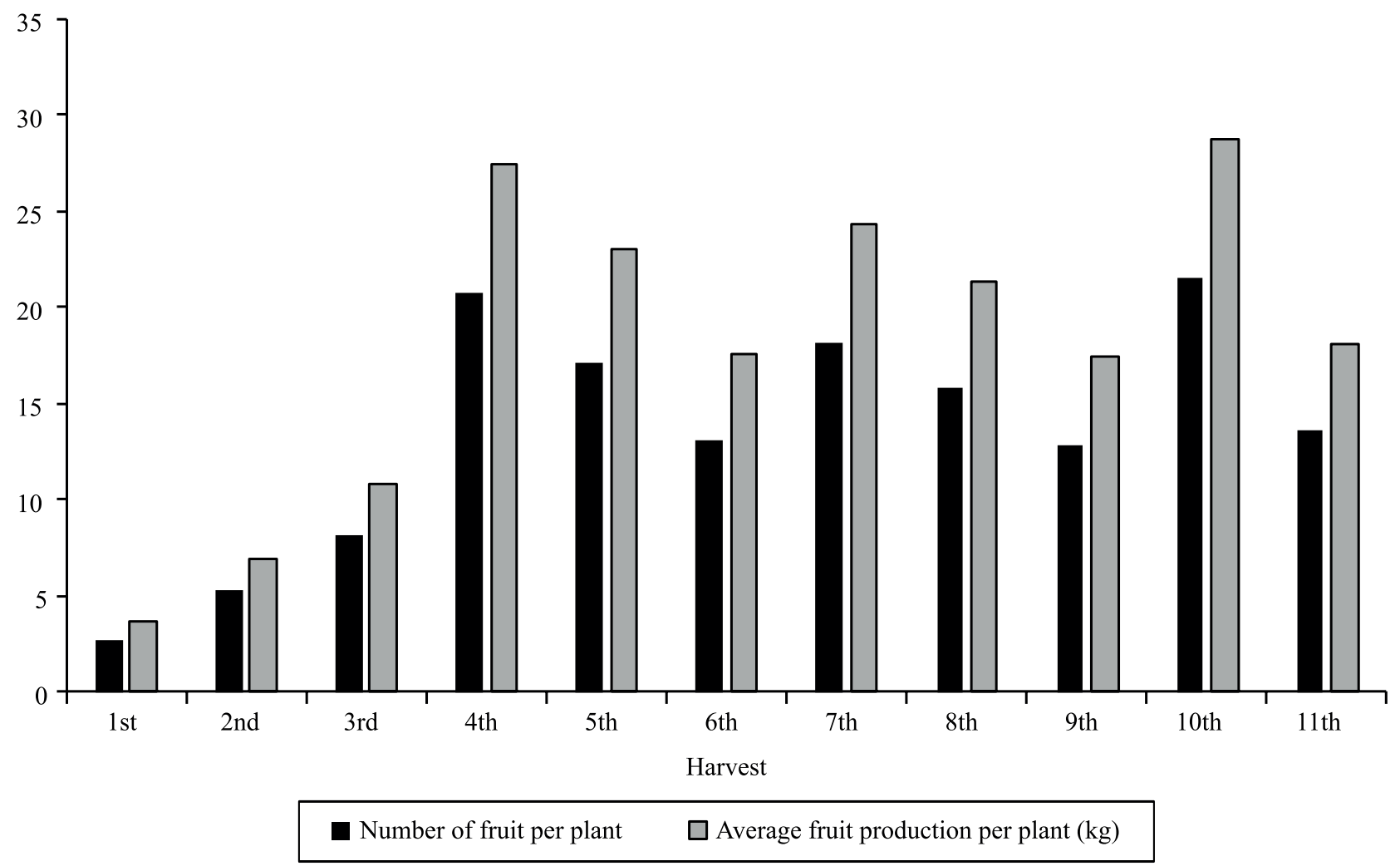

Figure 2. Average number of fruit per plant and average fruit production per plant (kg), for eleven harvests (from $2007 / 2008$ to 2018/2019), in an experimental trial of full-sib cupuaçu (Theobroma grandiflorum) progenies. 
with an irrigation system, which supplemented the need for water during the critical period of the year, providing optimal growing conditions. Later, the irrigation system was removed from the AFS. Thus, fruit production depended exclusively on rainfall, which occurred in the period immediately before harvest (July to December), as well as in the flowering period and in the beginning of fruiting (Venturieri, 2011), leading to annual fluctuations in the production from the fourth harvest onward. When evaluating the behavior of Theobroma cacao in response to variations of water availability in the soil, García Lozano \& Fonseca (2016) found a decrease of plant metabolism during water shortage, which was attributed mainly to the stomatal closure that paralyzes photosynthesis and, consequently, the production of photoassimilates.

Based on the likelihood ratio test (LRT), the genetic effects were significant, while the plot effects were not significant $(p<0.05)$ for the average number of fruit and average fruit production (Table 1). Therefore, for both traits there was a genetic variability between fullsib progenies of cupuaçu, and the plot effects did not differ from zero.

The estimated genotypic variance among the fullsib progenies was reasonably high, especially for the variable "fruit production" (Table 2). This is a desirable outcome, as it indicates a high genetic variability and supports the possibility of successful selection (Rosado et al., 2012). Corroborating this result, the selective accuracies were high $\left(0.70<\mathrm{r}_{\mathrm{gg}}<0.90\right)$ for the two traits, based on the classification proposed by Resende \& Duarte (2007). According to Resende (2002), the selective accuracy refers to the correlation between the predicted and true genetic values, and it is closely

Table 1. Analyses of deviance for the traits average number of fruit per plant and average fruit production per plant, evaluated in an experimental trial of full-sib cupuaçu (Theobroma grandiflorum) families.

\begin{tabular}{lccccc}
\hline Effect & \multicolumn{2}{c}{$\begin{array}{c}\text { Average number of fruit } \\
\text { per plant }\end{array}$} & & \multicolumn{2}{c}{$\begin{array}{c}\text { Average fruit production } \\
\text { per plant }(\mathrm{kg})\end{array}$} \\
\cline { 2 - 3 } \cline { 5 - 6 } & Deviance & LRT & & Deviance & LRT \\
\hline Progeny & $1,427.22$ & $28.83^{*}$ & & $1,698.88$ & $21.42^{*}$ \\
Plot & $1,398.76$ & $0.37^{\mathrm{ns}}$ & & $1,677.46$ & $0.00^{\mathrm{ns}}$ \\
Complete model & $1,398.39$ & - & & $1,677.46$ & - \\
\hline
\end{tabular}

LRT: likelihood ratio test. *Significant at $5 \%$ type I probability of error

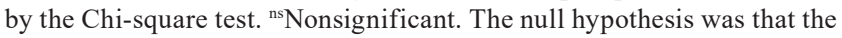
complete and reduced models do not differ from each other. associated with the experimental quality. As verified through the LRT, the coefficient of determination of plot effects was practically nil, which can explain the minor environmental heterogeneity between plots (Alves \& Resende, 2008).

The high estimates for average progenies heritability (Table 2) reinforce the potential for genetic selection (Rosado et al., 2012). Moreover, moderate but reasonable values for individual narrowsense heritability were observed $\left(0.15<\mathrm{h}_{\mathrm{a}}^{2}<0.50\right)$ (Resende, 2015) (Table 2), considering the polygenic control of the traits, which are significantly influenced by the environmental effects. This difference is clear when analyzing the work of Maia et al. (2011), in which the traits fruit length, which is of oligogenic nature, showed narrow-sense heritability of $64 \%$, while the traits fruit weight showed $16 \%$ narrow-

Table 2. Estimates of variance components and genetic parameters for the traits average number of fruit per plant and average fruit production per plant, evaluated in an experimental trial of full-sib cupuaçu (Theobroma grandiflorum) families ${ }^{(1)}$.

\begin{tabular}{lcc}
\hline $\begin{array}{l}\text { Variance components } \\
\text { and genetic parameters }\end{array}$ & $\begin{array}{c}\text { Average number } \\
\text { of fruit per plant }\end{array}$ & $\begin{array}{c}\text { Average fruit production } \\
\text { per plant }(\mathrm{kg})\end{array}$ \\
\hline$\sigma_{\mathrm{g}}^{2}$ & 4.04 & 7.41 \\
$\sigma_{\mathrm{p}}^{2}$ & 0.13 & 0.04 \\
$\sigma_{\mathrm{e}}^{2}$ & 18.60 & 45.44 \\
$\sigma_{\mathrm{f}}^{2}$ & 22.79 & 52.90 \\
$\mathrm{~h}_{\mathrm{a}}^{2}$ & 0.35 & 0.28 \\
$\mathrm{c}_{\mathrm{p}}^{2}$ & 0.005 & 0.0008 \\
$\mathrm{~h}_{\mathrm{mp}}^{2}$ & 0.76 & 0.70 \\
$\mathrm{r}_{\mathrm{g} g}$ & 0.87 & 0.80 \\
$\mathrm{~h}_{\mathrm{ad}}^{2}$ & 0.21 & 0.16 \\
\hline
\end{tabular}

(1) $\sigma_{g}^{2}$, genotypic variance among full-sib progenies; $\sigma_{\mathrm{p}}^{2}$, environmental variance between plots; $\sigma_{\mathrm{e}}^{2}$, residual variance within plot; $\sigma_{\mathrm{f}}^{2}$, individual phenotypic variance; $\mathrm{h}_{\mathrm{a}}^{2}$, individual narrow-sense heritability; $\mathrm{c}_{\mathrm{p}}^{2}$, coefficient of determination of plot effects; $h_{m p}^{2}$, average progeny heritability; $\mathrm{r}_{\mathrm{gg}}$, progeny selection accuracy; and $\mathrm{h}_{\text {ad }}^{2}$, additive heritability within a plot. 
sense heritability. When evaluating a population of 370 cupuaçu plants, Alves \& Resende (2008) found narrow-sense heritability values for the number of fruit close to $25 \%$, which is lower than the value found in the present study; however, they evaluated only four harvests. Machado et al. (2002) identified a very strong progeny $\mathrm{x}$ harvest interaction in relation to productive traits of the species, suggesting that the behavior of progenies differ from one harvest to another, and it is dependent on environmental factors. In the present study, progenies were evaluated and selected based on the behavior over 11 harvests, thus providing a greater selective accuracy.

Table 3. Predicted genetic values for the traits average number of fruit per plant, average fruit production per plant, and rate of Moniliophthora perniciosa infection evaluated in an experimental trial of full-sib cupuaçu (Theobroma grandiflorum) families.

\begin{tabular}{|c|c|c|c|c|}
\hline \multirow[t]{2}{*}{ Progeny } & \multirow[t]{2}{*}{ Progenitors } & $\begin{array}{c}\text { Average } \\
\text { number of } \\
\text { fruit per plant }\end{array}$ & $\begin{array}{l}\text { Average fruit } \\
\text { production per } \\
\text { plant }(\mathrm{kg})\end{array}$ & \multirow{2}{*}{$\begin{array}{c}\text { Witches' } \\
\text { broom } \\
\text { incidence } \\
(\%)\end{array}$} \\
\hline & & Genetic value & Genetic value & \\
\hline 1 & $186 \times 286$ & 12.3 & 15.9 & 33 \\
\hline 4 & 174 x Sekó & 14.5 & 18.5 & 0 \\
\hline 5 & $186 \times 184$ & 13.5 & 18.3 & 0 \\
\hline 6 & $174 \times 184$ & 15.4 & 20.9 & 13 \\
\hline 8 & $186 \times$ Parau & 12.7 & 18.6 & 0 \\
\hline 9 & $215 \times 220$ & 13.9 & 18.8 & 20 \\
\hline 11 & $220 \times 286$ & 13.6 & 16.8 & 0 \\
\hline 13 & 1074 x Parau & 13.0 & 20.1 & 60 \\
\hline 17 & $174 \times 220$ & 12.9 & 17.2 & 26 \\
\hline 19 & $174 \times 286$ & 13.1 & 15.2 & 0 \\
\hline 20 & $186 \times 1074$ & 11.9 & 16.9 & 0 \\
\hline 21 & $186 \times 215$ & 13.8 & 21.0 & 6 \\
\hline 22 & $174 \times 1074$ & 12.7 & 19.2 & 33 \\
\hline 23 & 215 x Sekó & 14.0 & 19.2 & 13 \\
\hline 25 & $215 \times 286$ & 13.1 & 16.4 & 0 \\
\hline 28 & $174 \times 186$ & 11.1 & 15.0 & 0 \\
\hline 29 & $173 \times 186$ & 11.3 & 15.2 & 0 \\
\hline 30 & $220 \times$ Parau & 11.6 & 15.4 & 26 \\
\hline 36 & 174 x M45 & 16.5 & 19.7 & 20 \\
\hline 37 & 186 x M138 & 17.6 & 21.2 & 6 \\
\hline 38 & $215 \times 554$ & 11.7 & 16.0 & 6 \\
\hline 40 & $174 \times 554$ & 12.0 & 14.4 & 6 \\
\hline 43 & $220 \times 12$ & 13.3 & 18.0 & 60 \\
\hline 49 & 174 x Hans 1 & 15.3 & 20.0 & 0 \\
\hline 52 & $174 \times 217$ & 16.6 & 22.5 & 20 \\
\hline Average & & 13.5 & 18.0 & 11.12 \\
\hline CV (\%) & & 12.6 & 12.5 & \\
\hline
\end{tabular}

$\mathrm{CV}$, coefficient of variation.
The average number of fruit per plant during the 11 analyzed harvests was 13.5 , and each plant produced the average of $18.0 \mathrm{~kg}$ of fruit (Table 3). Five progenies $(6,36,37,49$, and 52$)$ had the highest genetic values, considering both the number of fruit and total fruit production per plant (Table 3). These progenies showed phenotypic values for average fruit production greater than $20 \mathrm{~kg}$ of fruit per plant per harvest, which resulted in an estimated $8 \mathrm{Mg} \mathrm{ha}^{-1}$ fruit, considering the density of 400 plants $\mathrm{ha}^{-1}$. This value is similar to the yield obtained by the cultivar BRS Carimbó eight years after cultivation (Alves \& Ferreira, 2012).

Progenies 6, 37, and 49 showed low rates of damage caused by $M$. perniciosa (the causal agent of witches' broom disease), at less than $15 \%$ (Table 4), while 20\% of the plants of progenies 36 and 52 were symptomatic. It is worth noting that for four of the five selected progenies, clone 174 ('BRS Coari') was the maternal parent (Table 3). In previous studies, this clone stood out as an excellent source of resistance not only to M. perniciosa, but also to progressive cupuaçu death, caused by the fungus Lasiodiplodia theobromae (Alves et al., 2018b). In studies on the cupuaçu genotype selection, the resistance to M. perniciosa is extremely important. One of the highest costs associated with maintaining an orchard is related to the control of this disease (Souza, 2007), as there is a need for constant vigilance, phytosanitary pruning, and application of fungicides. Therefore, the genetic improvement of cupuaçu through the selection of individuals resistant to these two diseases is the most sustainable option, as it is more economically viable and has no environmental impact (Furlan et al., 2010).

Another nine progenies $(4,5,8,9,13,21,22,23$, and 43) had genetic values similar to those of the five progenies mentioned above for the trait fruit production; however, these progenies showed lower values for the number of fruit per plant. This can be explained by the fact that they have larger and heavier fruit, but produce relatively few fruit. Progenies 4, 5, 8, 21, and 23 are of particular interest, as they show low rates of witches' broom disease symptoms (Table 3). Progenies 4 and 23 also call special attention, as they include the 'Sekó' genotype, which is a new source of resistance to $M$. pernicious that is geographically different from those currently being developed in this breeding program, thus contributing to the pyramidization of resistance genes. The hybrids obtained through 
crosses using the cultivars 'BRS Coari' (174) and 'BRS Manacapuru' (215) reinforce the importance of these progenies for the breeding program, as crosses based on more productive clones may produce genetic materials that maintain the resistance of these genotypes, while incorporating the productivity of the third parent.

The above mentioned progenies showed few plants with symptoms of witches' broom disease over the 14 years of the experiment, thus providing the evidence of good levels of field resistance (Table 3). However, most ortets with symptoms were from progenies 13 and 43, reflecting high susceptibility to $M$. pernicious. For progeny 13, this behavior was expected, since both parents showed susceptibility to the disease (Alves et al., 2009). The objective of this crossing was to concentrate productivity genes from both parents. Thus, despite its susceptibility, it may be interesting in the future to select at least one ortet with high fruit production within this family to be used in hybridization with resistant genotypes. However, the behavior of progeny 43 was unexpected. Although the male parent (clone 12) was highly susceptible, the other parent (clone 220) showed good resistance in other crossings (progenies 9, 11, 17, and 38). From this, it can be concluded that the susceptibility genes of the second parent (clone 12) prevailed in those progenies. According to Alves et al. (2009), genes related to witches' broom resistance in cupuaçu are in heterozygosis, which is why parents that are resistant may produce progenies that are susceptible to the disease.
Hybridization, the method used to produce the progenies of the present study, seeks to consolidate the favorable alleles present in two genitors into a single individual (Baldissera et al., 2014). In the present work, productive and low-resistance genotypes were crossed with resistant genotypes, but the results were unsatisfactory for productivity. The choice of genetically distinct genitors may increase the efficiency of crosses.

After the identification of the superior progenies, the best individuals were identified and selected. In order to maintain the genetic variability in the population, and to guarantee a broad genetic base, two ortets per progeny were selected. Individuals were selected based on the genetic and genotypic values, excluding individuals whose progenies had high incidence rates of $M$. pernicious (Table 4). No discrepancies were found between the two lists of selected individuals. That is, the same individuals selected on the basis of genotypic values were also selected on the basis of genetic values. Similar results were obtained by Alves et al. (2010). The production from the ten clones originating from these individuals can provide an mean gain of $7.33 \mathrm{~kg}$ of fruit per plant, which corresponds to $40 \%$ increase over the original population. If these clones are used to establish a seed orchard, a gain of $6.15 \mathrm{~kg}$ of fruit per plant is expected, corresponding to $34 \%$ increase in relation to the initial situation. According to Alves et al. (2010), the use of clones as planting material narrows the genetic base, therefore, planted populations should always consist

Table 4. Individuals selected for clonal propagation with the genetic values and genetic gains of clones (kg per plant), and genetic values and genetic gains of genitors (kg per plant), based on average fruit production per plant $(\mathrm{kg})$ and productive period of cupuaçu (Theobroma grandiflorum).

\begin{tabular}{lccccc}
\hline Individual $^{(1)}$ & \multicolumn{3}{c}{ Fruit production per plant (kg) } & \multicolumn{2}{c}{$\begin{array}{c}\text { Productive } \\
\text { classification }\end{array}$} \\
\cline { 2 - 5 } & Genotypic value & Genetic gain (clones) & Genetic value & Genetic gain (genitors) & Late \\
\hline 52.2 .1 & 28.9 & 10.96 & 27.1 & 9.1 & Regular \\
52.3 .2 & 26.7 & 9.84 & 25.5 & 8.3 & Regular \\
37.3 .1 & 25.7 & 9.13 & 24.4 & 7.4 & Late \\
37.5 .3 & 23.2 & 6.91 & 22.6 & 5.7 & Late \\
6.1 .3 & 23.2 & 6.62 & 22.5 & 5.6 & Late \\
49.5 .1 & 23.0 & 6.40 & 22.2 & 5.3 & Early \\
49.5 .3 & 22.8 & 6.13 & $22 . .0$ & 5.3 & Regular \\
6.5 .2 & 22.8 & 5.84 & 22.3 & 5.5 & Regular \\
36.3 .2 & 22.5 & 5.35 & 21.7 & 5.0 & Early \\
36.1 .2 & 21.8 & 21.1 & 4.3 & \\
\hline
\end{tabular}

${ }^{(1)}$ Coding of individuals x.y.z, where x corresponds to the progeny, y corresponds to the block, and z, to the plant. 
of five or more genotypes, in order to avoid the risk of epidemics caused by the fungus $M$. perniciosa. This precaution also applies to the selection of clones used as progenitors which, through interbreeding, will produce seed with a broad genetic base.

As to the production period, two selected individuals were considered early, four were regular, and four, late. This balancing of the productive season is important to avoid the concentration of production in a single period of the year, which complicates the logistics of the agroindustry and reduces the price paid to the producer due to excess supply (Hojo et al., 2007).

A good adaptability of the tested progenies to AFS conditions was observed due to the seasonal pattern of fruit production (Table 4). Thus, it was indirectly observed that, along with favorable agronomic traits, the genotypes offer tolerance to the conditions present in AFS environments, such as the competition for light, water, and nutrients. Nevertheless, attention should be paid to the choice of the species that will be used in consortium with cupuaçu. Alves et al. (2018a), when studying the interaction of taperebazeiro (Spondias mombin L.) with cupuaçu in an AFS, reported the viability of the consortium due to the fact that no significant losses were observed in the production of cupuaçu fruit. When choosing the species that will compose the AFS, plants that exploit different strata, both above and below ground, are recommended to avoid competition for light, nutrients, and water (Condé et al., 2013). As to this fact, competition with bacuri was probably mitigated by the fact that grafted seedlings were used, which promotes slower growth than seminal seedlings and produces smaller and more compact plants. As there is economic interest in both species, this consortium is advantageous for producers because it combines two potential products of Amazonian fruit culture (Porte et al., 2010). In addition, both are native species, which increases the likelihood of success due to their adaptability to Amazonian conditions.

\section{Conclusions}

1. The agroforestry system allows of the discrimination of the most adaptable cupuaçu (Theobroma grandiflorum) tree genotypes.

2. Cupuaçu tree progenies 6 (174 x 184), 36 (174 x M45), 37 (186 x M138), 49 (174 x Hans 1), and 52 (174 $x$ 217), are the ones that best adapt to the environment of an agroforestry system due to their agronomic traits, under competitive conditions.

3. Ten matrices show agronomic potential and indirect adaptation to the agroforestry system, and they should be used as clonal cupuaçu cultivars in this environment.

\section{Acknowledgments}

To Conselho Nacional de Desenvolvimento Científico e Tecnológico (CNPq), to Coordenação de Aperfeiçoamento de Pessoal de Nível Superior (Capes, Finance Code 001), to Fundação de Amparo à Pesquisa do Estado de Minas Gerais (Fapemig), and to Embrapa Amazônia Oriental, for financial support; to José Quadros, José Oliveira, and Antônio Fontel, for the years of great labor; and to the rural producer Michinori Konagano, for the partnership.

\section{References}

ALVES, R.M.; BASTOS, A.J.R.; CHAVES, S.F. da S.; FERNANDES, J.R.Q. Spondias mombin and Theobroma grandiflorum in agroforestry system: productivity implications. Revista Brasileira de Fruticultura, v.40, e-061, 2018a. DOI: https://doi.org/10.1590/0100-29452018061.

ALVES, R.M.; BENCHIMOL, R.L.; OLIVEIRA, R.P. de; CHAVES, S.F. da S. Resistência de genótipos de cupuaçuzeiro a Lasiodiplodia theobromae. Belém: Embrapa Amazônia Oriental, 2018b. 19p. (Embrapa Amazônia Oriental. Boletim de pesquisa e desenvolvimento, 128). Available at: $<$ https:/ainfo. cnptia.embrapa.br/digital/bitstream/item/187910/1/TC-04-18BPD-128-V03.pdf>. Accessed on: Nov. 182020.

ALVES, R.M.; CHAVES, S.F. da S.; GAMA, M.A.P.; PEDROZA NETO, J.L.; SANTOS, T.G. dos. Simultaneous selection of cupuassu tree and Brazilian mahogany genotypes in an agroforestry system in Pará state, Brazil. Acta Amazonica, v.50, p.183-191, 2020. DOI:_https://doi.org/10.1590/1809-4392202000711.

ALVES, R.M.; FERREIRA, F.N. BRS Carimbó: a nova cultivar de cupuaçuzeiro da Embrapa Amazônia Oriental. Belém: Embrapa Amazônia Oriental, 2012. 232p. (Embrapa Amazônia Oriental. Comunicado técnico, 232). Available at: $<$ https://www. infoteca.cnptia.embrapa.br/bitstream/doc/918443/1/COM232. pdf $>$. Accessed on: Nov. 182020.

ALVES, R.M.; RESENDE, M.D.V. de. Avaliação genética de indivíduos e progênies de cupuaçuzeiro no estado do Pará e estimativas de parâmetros genéticos. Revista Brasileira de Fruticultura, v.30, p.696-701, 2008. DOI: https://doi.org/10.1590/ S0100-29452008000300023.

ALVES, R.M.; RESENDE, M.D.V. de; BANDEIRA, B. dos S.; PINHEIRO, T.M.; FARIAS, D.C.R. Evolução da vassoura-de- 
bruxa e avaliação da resistência em progênies de cupuaçuzeiro. Revista Brasileira de Fruticultura, v.31, p.1022-1032, 2009. DOI: https://doi.org/10.1590/S0100-29452009000400015.

ALVES, R.M.; RESENDE, M.D.V. de; BANDEIRA, B. dos S.; PINHEIRO, T.M.; FARIAS, D.C.R. Avaliação e seleção de progênies de cupuaçuzeiro (Theobroma grandiflorum), em Belém, Pará. Revista Brasileira de Fruticultura, v.32, p.204-212, 2010. DOI: https://doi.org/10.1590/S0100-29452010005000010.

ALVES, R.M.; SEBBENN, A.M.; ARTERO, A.S.; CLEMENT, C.; FIGUEIRA, A. High levels of genetic divergence and inbreeding in populations of cupuassu (Theobroma grandiflorum). Tree Genetics \& Genomes, v.3, p.289-298, 2007. DOI: https://doi.org/10.1007/s11295-006-0066-9.

ALVES, R.M.; SILVA, C.R. de S.; ALBUQUERQUE, P.S.B. de; SANTOS, V.S. dos. Phenotypic and genotypic characterization and compatibility among genotypes to select elite clones of cupuassu. Acta Amazonica, v.47, p.175-184, 2017. DOI: https://doi.org/10.1590/1809-4392201602104.

BALDISSERA, J.N. da C.; VALENTINI, G.; COAN, M.M.D.; GUIDOLIN, A.F.; COIMBRA, J.L.M. Fatores genéticos relacionados com a herança em populações de plantas autógamas. Revista de Ciências Agroveterinárias, v.13, p.181-189, 2014.

BARROS, A.V.L. de; HOMMA, A.K.O.; TAKAMATSU, J.A.; TAKAMATSU, T.; KONAGANO, M. Evolução e percepção dos sistemas agroflorestais desenvolvidos pelos agricultores nipo-brasileiros do município de Tomé-Açu, estado do Pará. Amazônia: Ciência \& Desenvolvimento, v.5, 121-151, 2009.

BOLFE, E.L.; BATISTELLA, M. Análise florística e estrutural de sistemas silviagrícolas em Tomé-Açu, Pará. Pesquisa Agropecuária Brasileira, v.46, p.1139-1147, 2011. DOI: https://doi.org/10.1590/S0100-204X2011001000004.

CONDÉ, T.M.; LIMA, M.L.M. de; LIMA NETO, E.M. de; TONINI, H. Morfometria de quatro espécies florestais em sistemas agroflorestais no munícipio de Porto Velho, Rondônia. RevistaAgro@mbiente On-line, v.7, p.18-27, 2013. DOI: https://doi.org/10.18227/1982-8470ragro.v7i1.932.

FURLAN, C.R.C.; DANTAS, A.C.M.; DENARDI, F.; BECKER, W.F.; MANTOVANI, A. Resistência genética dos acessos do banco de germoplasma de macieira da Epagri à mancha foliar de Glomerella (Colletotrichum gloeosporioides). Revista Brasileira de Fruticultura, v.32, p.507-514, 2010. DOI: https://doi.org/10.1590/S0100-29452010000200022.

GARCÍA LOZANO, J.; FONSECA, L.P.M. Respuestas fisiológicas de Theobroma cacao L. en etapa de vivero a la disponibilidad de agua en el suelo. Acta Agronómica, v.65, p.44-50, 2016. DOI: https://doi.org/10.15446/acag.v65n1.48161.

GIUSTINA, C.D.; CARNEVALLI, R.A.; ROMANO, M.R.; ANTONIO, D.B.A.; ECKSTEIN, C. Growth of different fruit tree species in silvopastoral systems during the establishment phase. Revista Caatinga, v.30, p.1040-1049, 2017. DOI: https://doi.org/10.1590/1983-21252017v30n425rc.

HENDERSON, C.R. Best linear unbiased estimation and prediction under a selection model. Biometrics, v.31, p.423-447, 1975. DOI: https://doi.org/10.2307/2529430.
HOJO, R.H.; CHALFUN, N.N.J.; HOJO, E.T.D.; VEIGA, R.D.; PAGLIS, C.M.; LIMA, L.C.O. Produção e qualidade dos frutos da goiabeira 'Pedro Sato' submetida a diferentes épocas de poda. Pesquisa Agropecuária Brasileira, v.42, p.357-362, 2007. DOI: https://doi.org/10.1590/S0100-204X2007000300008.

MACHADO, G.M.E.; REGAZZI, A.J.; VIANA, J.M.S.; CRUZ, C.D.; GRANATE, M.J. Estimação de parâmetros genéticos de uma população amazônica de cupuaçuzeiro (Theobroma grandiflorum (Willd ex Spreng) Schum). Revista Ceres, v.49, p.13-27, 2002.

MAIA, M.C.C.; RESENDE, M.D.V. de; OLIVEIRA, L.C. de; ALVES, R.M.; SILVA FILHO, J.L. da; ROCHA, M. de M.; CAVAlCANTE, J.J.V.; RONCATtO, G. Análise genética de famílias de meios-irmãos de cupuaçuzeiro. Pesquisa Florestal Brasileira, v.31, p.123-130, 2011. DOI: https://doi.org/10.4336/2011.pfb.31.66.123.

OLIVEIRA, T.B. de; GENOVESE, M.I. Chemical composition of cupuassu (Theobroma grandiflorum) and cocoa (Theobroma cacao) liquors and their effects on streptozotocin-induced diabetic rats. Food Research International, v.51, p.929-935, 2013. DOI: https://doi.org/10.1016/j.foodres.2013.02.019.

PALUDO, R.; COSTABEBER, J.A. Sistemas agroflorestais como estratégia de desenvolvimento rural em diferentes biomas brasileiros. Revista Brasileira de Agroecologia, v.7, p.63-76, 2012.

PATTERSON, H.D.; THOMPSON, R. Recovery of inter-block information when block sizes are unequal. Biometrika, v.58, p.545-554, 1971. DOI: https://doi.org/10.1093/biomet/58.3.545.

PORTE, A.; REZENDE, C.M.; ANTUNES, O.A.C.; MAIA, L.H. Redução de aminoácidos em polpas de bacuri (Platonia insignis Mart), cupuaçu (Theobroma grandiflorum Willd ex-Spreng Schum) e murici (Byrsonima crassifolia L.) processado (aquecido e alcalinizado). Acta Amazonica, v.40, p.573-578, 2010. DOI: https://doi.org/10.1590/S0044-59672010000300017.

RESENDE, M.D.V. de. Genética biométrica e estatística no melhoramento de plantas perenes. Brasília: Embrapa Informação Tecnológica, 2002. 975p.

RESENDE, M.D.V. de. Genética quantitativa e de populações. Viçosa: Suprema, 2015. 463p.

RESENDE, M.D.V. de. Software Selegen-REML/BLUP: a useful tool for plant breeding. Crop Breeding and Applied Biotechnology, v.16, p.330-339, 2016. DOI: https://doi.org/10.1590/1984-70332016v16n4a49.

RESENDE, M.D.V. de; DUARTE, J.B. Precisão e controle de qualidade em experimentos de avaliação de cultivares. Pesquisa Agropecuária Tropical, v.37, p.182-194, 2007.

RESENDE, M.D.V. de; SILVA, F.F. e; AZEVEDO, C.F. Estatística matemática, biométrica e computacional: modelos mistos, multivariados, categóricos e generalizados (REML/BLUP), inferência bayesiana, regressão, aleatória, seleção genômica, QTL, GWAS, estatística espacial e temporal, competição, sobrevivência. Viçosa: Ed. da UFV, 2014. 881p.

ROSADO, A.M.; ROSADO, T.B.; ALVES, A.A.; LAVIOLA, B.G.; BHERING, L.L. Seleção simultânea de clones de eucalipto 
de acordo com produtividade, estabilidade e adaptabilidade. Pesquisa Agropecuária Brasileira, v.47, p.964-971, 2012. DOI: https://doi.org/10.1590/S0100-204X2012000700013.

SANTOS, H.G. dos; JACOMINE, P.K.T.; ANJOS, L.H.C. dos; OLIVEIRA, V.Á. de; LUMBRERAS, J.F.; COELHO, M.R.; ALMEIDA, J.A. de; ARAÚJO FILHO, J.C. de; OLIVEIRA, J.B. de; CUNHA, T.J.F. Sistema brasileiro de classificação de solos. 5.ed. rev. e ampl. Brasília: Embrapa, 2018. 356p.

SILVA, D.P. da. SAFs: sistemas alternativos de produção. Revista de Extensão e Estudos Rurais, v.2, p.153-162, 2013. DOI: https://doi.org/10.36363/rever212013\%25p.

SOUZA, A. das G.C. de (Ed.). Boas práticas agrícolas da cultura do cupuaçuzeiro. Manaus: Embrapa Amazônia Ocidental, 2007. 56p.
VENTURIERI, G.A. Flowering levels, harvest season and yields of cupuassu (Theobroma grandiflorum). Acta Amazonica, v.41, p.143-152, 2011. DOI: https://doi.org/10.1590/S004459672011000100017.

VENTURIERI, G.A.; RIBEIRO FILHO, A.A. Polinização manual no cupuaçuzeiro (Theobroma grandiflorum). Acta Amazonica, v.25, p.181-191, 1995. DOI: https://doi.org/10.1590/180943921995253192.

WILKS, S.S. The large-sample distribution of the likelihood ratio for testing composite hypothesis. Annals of Mathematical Statistics, v.9, p.60-62, 1938. DOI: https://doi.org/10.1214/ aoms $/ 1177732360$. 